ECOLOGICA, Vol. 28, No 103 (2021), 331-339

https://doi.org/10.18485/ecologica.2021.28.103.1

Scientific paper

UDC: $347.72 .036:[616.98: 578.834$

\title{
COVID-19 Pandemic as a Challenge and Opportunity for Reaching the Sustainable Development Goals
}

\section{Pandemija COVID-19 kao izazov i prilika za postizanje ciljeva održivog razvoja}

\author{
Antoaneta Vassileva ${ }^{1 *}$, Milica Simić ${ }^{2}$ \\ ${ }^{1}$ Faculty for International Economics and Politics, University of National and World Economy, Sofia, Bulgaria / \\ Fakultet za međunarodnu ekonomiju i politiku, Univerzitet za nacionalnu i svetsku ekonomiju, Sofija, \\ Bugarska \\ ${ }^{2}$ Faculty for Finance, Banking and Audit, Alfa BK University, Belgrade, Serbia / \\ Fakultet za finansije, bankarstvo i reviziju, Alfa, BK Univerzitet, Beograd, Srbija \\ ${ }^{*}$ Corresponding author / Autor za prepisku
}

Received / Rad primljen: 21.12.2020, Accepted / Rad prihvaćen: 10.08.2021.

\begin{abstract}
The coronavirus pandemic which started in 2019, has a dramatic influence on the global economic activity - disrupting of industrial production, decrease of merchandise trade and services, derailing economic growth, financial market volatility, shrinking of the global supply chains, limiting the traveling and last but not least, reduction of income of people and rising insecurity. The slowdown of the world economy has a direct impact on the sustainable development and reaching the goals of the Agenda 2030.

The pandemic presents both an enormous challenge and new opportunities, it may affect positively or delay the achievement of the Sustainable Development Goals (SDGs). In order to recover from this crisis stronger and launch a new path towards economic revival the international organizations have undertaken a number of measures to combat the coronavirus pandemic. The UN has mobilized the full capacity of the UN system through its 131 country teams serving 162 countries and territories, to support national authorities in developing public health preparedness and response plans to the COVID-19 crisis. The UN estimates that "a multilateral response of about $10 \%$ of global GDP will be needed". The economic policy of the governments of the affected countries has been directed to mitigation of the negative effects and adoption of fiscal and monetary stimuli. The EU and the US have already announced tremendous financial packages to help the economies of their countries, and many other developed nations are following similar steps. The governments of many countries undertook unpopular measures which appeared to be "the new normality". However, developing countries may not afford financial stimuli due to their very high debt levels. Rich and poor, the pandemic has forced all the people to reconsider almost every aspect of their life.

The purpose of this paper is to analyze the impact of COVID-19 on the implementation of the SDGs. It examines its implications in a global economic context and answers the question whether it is a threat or a chance in reaching the SDGs. The attention is focused on the response of the UN and the measures for combating the coronavirus pandemic. The authors assign priority to the key messages from the Financing for Sustainable Development Report 2020 of the UN and the targeted areas and actions to promote stability. The opportunities and mechanisms for a green recovery of the economy have been discussed. An emphasis is put on the EU Green Deal as a roadmap to sustainable development. The paper has a standard structure, the methodology is based on desk research, i.e. a survey of specialized literature, papers and documents of the UN, UNDP, UNIDO, OECD, EC, as well as quantitative evaluation of statistical information and analysis of the current world trends.
\end{abstract}

Key words: COVID-19, sustainable development, SDGs, Green Deal, green recovery. 
Sažetak: Pandemija koronavirusa koja je započela 2019. godine ima dramatičan uticaj na globalnu ekonomsku aktivnost - poremećaj industrijske proizvodnje, smanjenje trgovine robama i uslugama, pad ekonomskog rasta, nestabilnost finansijskog tržišta, skraćivanje globalnih lanaca snabdevanja, ograničavanje putovanja i poslednje, ali ne najmanje važno, smanjenje ličnog dohotka stanovništva i rastuća nesigurnost. Usporavanje svetske ekonomije ima direktan uticaj na održivi razvoj i dostizanje ciljeva Agende 2030.

Pandemija predstavlja ogroman izazov i nove mogućnosti, može pozitivno uticati ili odložiti postizanje ciljeva održivog razvoja (SDG). Da bi se snažnije oporavile od ove krize i pokrenule novi put ka ekonomskom oživljavanju, međunarodne organizacije su preduzele niz mera u borbi protiv pandemije koronavirusa. UN su mobilizirale puni kapacitet sistema UN-a preko svog tima iz 131 zemlje koji opslužuju 162 zemlje i teritorije, kako bi podržale nacionalne vlasti u razvoju planova spremnosti javnog zdravlja i odgovora na krizu COVID-19. UN procenjuju da će „biti potreban multilateralni odgovor od oko 10\% globalnog BDP-a“. Ekonomska politika vlada pogođenih zemalja bila je usmerena na ublažavanje negativnih efekata i usvajanje fiskalnih i monetarnih podsticaja. EU i SAD su već najavile ogromne finansijske pakete za pomoć ekonomijama svojih zemalja, a mnoge druge razvijene države slede slične korake. Vlade mnogih zemalja preduzele su nepopularne mere koje su izgledale kao „nova normalnost“. Međutim, zemlje u razvoju možda neće priuštiti finansijske podsticaje zbog vrlo visokog nivoa duga. Pandemija je primorala sve ljude - bogate i siromašne - da preispitaju gotovo svaki aspekt svog života.

Svrha ovog rada je da analizira uticaj COVID-19 na sprovođenje cileva održivog razvoja. Istraživanje ispituje njegove implikacije u globalnom ekonomskom kontekstu i odgovara na pitanje da li predstavlja pretnju ili šansu u postizanju ciljeva održivog razvoja. Pažnja je usmerena na odgovor UN-a i mere za borbu protiv pandemije koronavirusa. Autori daju prioritet ključnim porukama iz Izveštaja UN o finansiranju održivog razvoja 2020. i ciljanim oblastima i akcijama za promociju stabilnosti. Analiziraju se mogućnosti i mehanizmi za zelenu obnovu ekonomije. Akcenat je stavljen na Zeleni sporazum EU kao putokaz za održivi razvoj. Rad ima standardnu strukturu, metodologija se zasniva na desk istraživanju, odnosno istraživanju specijalizovane literature, radova i dokumenata UN-a, UNDP-a, UNIDO-a, OECDa, EK, kao i kvantitativnoj proceni statističkih podataka i analizi trenutnih svetskih trendova.

Ključne reči: COVID-19, održivi razvoj, ciljevi održivog razvoja, zeleni sporazum, zelena obnova ekonomije.

${ }^{1}$ orcid.org/0000-0002-5861-641X, e-mail: a.vasileva@unwe.bg

²orcid.org/0000-0002-0652-3799, e-mail: milica.simic@alfa.edu.rs

\section{INTRODUCTION}

The coronavirus pandemic which started in 2019 has a considerable impact on the economy and society. According to the UNDP Administrator Achim Steiner its consequences seem rather pessimistic: "The world has seen many crises over the past 30 years, including the Global Financial Crisis of 200709. Each has hit human development hard but, overall, development gains accrued globally year-onyear. COVID-19, with its triple hit to health, education, and income, may change this trend" (UNDP, 2020).

COVID-19 has shaken the global economic landscape. In view of its repercussions, experts have recently referred to the rapidly spreading coronavirus as the "black swan" of the economy. This concept characterizes rare and surprising events, which, however, have the potential to cause devastating effects on the financial world and the real economy (Ivanović, Vujić, 2021). It has affected the economy mainly through declining of exports, which affects global economic activity, decrease in demand as a consequence of measures and policies of entry restrictions that reduced travel, and reduction of domestic private consumption, which impacts the slump of international business operations (Jancović et al., 2021). Its dramatic influence on the global economic activity is mostly seen in disrupting of industrial production, decrease of merchandise trade and services, derailing economic growth, financial market volatility, shrinking of the global supply chains, limiting the traveling and last but not least, reduction of income of people and rising insecurity. The slowdown of the world economy has a direct impact on the sustainable development and reaching the goals of the Agenda 2030.

The coronavirus pandemic gave rise to a public health emergency which led to economic turmoil that world leaders have compared to the aftermath of WWII. The crisis forced the international organizations and national governments to implement diverse measures in an attempt to curtail the pandemic and support the economy (Pedamon, Vassileva, 2021).

The aim of this paper is to analyze the impact of COVID-19 on sustainable development. It examines its implications in a global economic context and answers the question whether it is a threat to achieving the SDGs. The attention is focused on the socio-economic response of the UN and the measures for combating the coronavirus pandemic. The key concepts to which the authors assign priority are the messages from the Financing for Sustainable Development Report 2020 of the UN and the targeted 
areas and actions to promote economic stability. The opportunities and mechanisms for a green recovery of the economy have been discussed. An emphasis is put on the EU Green Deal and the Action plan for a circular economy as a roadmap to sustainable development.

\section{MATERIALS AND METHODS}

The methodology of the paper is based on desk research, i.e., a survey of specialized literature, papers and documents of the UN, UNCTAD, UNDP, UNIDO, OECD, EC, IMF, etc., as well as quantitative evaluation of statistical information and analysis of the current world trends. The methods of comparison, study and analysis of books, scientific papers, websites and all scientific published texts related to sustainable development, the COVID-19 pandemic and the impact of the pandemic on economic indicators on a global level as well as the impact on the fulfilment of the Sustainable Development Goals (SDGs), have been applied. Then, induction and deduction methods have been used in drawing conclusions.

The paper investigates the direct and indirect impact of the pandemic on world economic activity during 2020 and the first quarter of 2021. The research focuses on the impact of COVID-19 on global GDP, economic activity and the labor market. The current effects of the pandemic manifested themselves negatively through a decline in the economic activity and the level of global GDP, a low investment rate and a slump in employment.

The starting hypothesis is that the COVID-19 pandemic had mostly negative as well as some positive effects on the economy and the environment, respectively on the SDGs, connected to them. The second hypothesis refers to the measures that have been undertaken by the international organizations and the governments to combat the pandemic, where the assumption is that joint efforts and cooperation are necessary to prevent the threat to reach the SDGs.

The paper also includes graphs that illustrate the main points of the discussion.

\section{RESULTS AND DISCUSSION}

\section{COVID-19 implications in a global economic context}

In the first quarter of 2020, the COVID-19 epidemic spread worldwide and negatively affected global economic growth. Estimates to date show that the expansion of the virus has globally reduced economic growth to an annual rate of $-4.5 \%$ to $-6.0 \%$ in 2020 , with a partial recovery of $2.5 \%$ to $5.2 \%$ in 2021. Global trade is estimated to have fallen by
$5.3 \%$ in 2020 , but is expected to grow by $8.0 \%$ in 2021. According to the consensus of forecasts, the economic downturn in 2020 was not as negative as initially estimated, at least partially, due to the fiscal and monetary policies adopted by the governments of the countries in 2020. The world's most developed economies predict that $60 \%$ of global economic activity will operate below its potential level of production by at least 2024. Compared to the synchronized nature of the global economic slowdown in the first half of 2020, the global economy showed signs of recovery that began in the third quarter of 2020 with developed economies that have just recovered, while economic growth in developing economies lags behind. The revival of cases of contamination in Europe, the United States, Japan, Brazil, India, and other developing economies has renewed calls for locks and curfews and threatens to weaken or delay a potentially sustainable economic recovery from mid to late 2021 (Bureau of Economic Analysis, 2021).

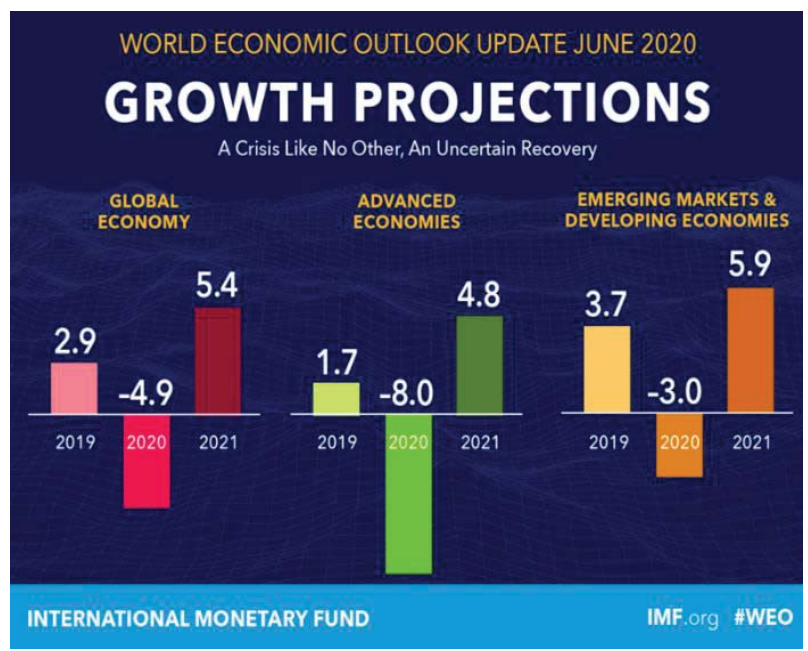

Figure 1 - World economic growth projections Source:

https://www.imf.org/en/Publications/WEO/Issues/20

21/03/23/world-economic-outlook-april-2021

The spread of the pandemic has left national economies and businesses to calculate costs, while governments are struggling with new locking measures to combat the spread of the virus. Despite the development of new vaccines, many are still wondering what the recovery might look like. Large shifts in stock markets, where stocks and companies are bought and sold, can affect the value of pensions or individual savings accounts (IMF, 2020). FTSE, industry average Dow Jones and Nikkei recorded huge declines as the number of COVID-19 cases grew in the first months of the crisis. Major Asian and US stock markets recovered after the 
announcement of the first vaccine in November, but FTSE is still in negative territory. FTSE fell $14.3 \%$ in 2020, its worst performance since 2008. In response, central banks in many countries have cut interest rates. This should, in theory, make borrowing cheaper and stimulate spending to stimulate the economy (IMF, 2021).

\section{The impact of COVID-19 on the sustainable development}

The pandemic presents both an enormous challenge and opportunities for reaching the 2030 Agenda and the Sustainable Development Goals (SDGs). The most widely recognized definition of sustainable development is given by the Norwegian Prime Minister Gro Harlem Brundtland in the Report of the World Commission on Environment and Development: Our Common Future released in 1987. That is, development that "meets the needs of the present without compromising the ability of future generations to meet their own needs" (UN, 1987). SDGs (Figure 2) are a set of 17 goals, including 169 targets which represent a measure for countries with regard to sustainable development and a sustainable future and ambition to eradicate extreme poverty, end inequality, protect the planet and generate universal peace. They were established in 2015 by the United Nations General Assembly and intended to be achieved by the year 2030 (United Nations, 2020). The SDGs resulted from one of the most inclusive and transparent consultation processes in the history of the United Nations. Together, they address the most important economic, social, environmental and governance challenges of our time. They are the first agenda set for open cooperation between public, private and social sectors, alongside citizens. Their success relies heavily on the joint action of all these actors (CRB, 2020).

\section{SUSTAINABLE DEVELOPMENT}
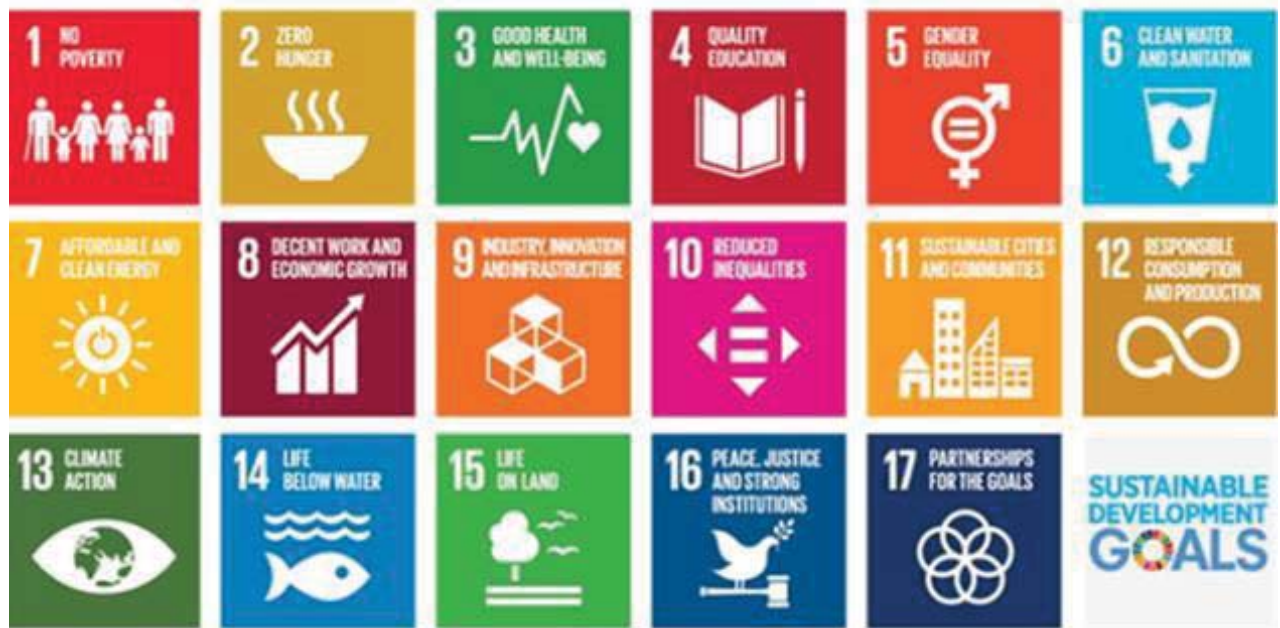

SUSTAINABLE

DEVELOPMENT GOALS

Figure 2 - Sustainable development goals

The SDGs are based on the Millennium Development goals (MDGs). Both are a natural evolution of the same idea, but the SDGs go much further. They expand the scope of the development agenda to include goals on economic growth, climate change, sustainable consumption, innovation, and the importance of peace and justice for all (UNDP, 2017). At their core, however, both the MDGs and the SDGs are the same: a belief that humanity, with sufficient determination and investment, has the ability to achieve sustainable development. A crucial difference between the MDGs and the SDGs is that the former were mainly targeted to governments while the latter target many different stakeholders including the private sector. Indeed, a shift in approach between the MDGs and the SDGs is the recognition that policy objectives are best achieved by involving and integrating private actors in the policy process (Marx, 2019). After the coronavirus pandemic has started, the SDGs received a grievous blow, one that will be far reaching for years to come. But the pandemic also shows the wisdom of what is already inherent in the SDGs, the challenges all the countries face cannot be dealt with in isolation. 
Since the initiative's primary foci of the SDGs were People, Planet, Prosperity, and Peace, it became obvious that the crisis hit most severely people and economy. The slowdown of the world economy has a direct impact on the SDGs, with a severe increase of poverty levels, unemployment and health risks as it is reported in the socioeconomic assessments of the UNDP (UNDP, 2020). A rise of the level of poverty is the most direct effect of the economic crisis of COVID-19. For SDG 1 (end poverty in all its forms everywhere), estimates show that it poses a real challenge for ending poverty by 2030. Global poverty could increase for the first time since 1990 and such increase could represent a reversal of a decade in the world's progress in reducing poverty. In some regions, poverty levels can come close to the numbers last seen 30 years ago (Sumner et al., 2020). Actually, the COVID-19 crisis is putting half a billion people in risk of poverty and an expected loss of income of around $20 \%$ can lead vulnerable segments of society to fall below poverty line. Income losses are expected to exceed USD 220 billion in developing countries (United Nations, 2020). These predictions can get worse if the crisis endures.

Unemployment has also risen and is estimated to turn 30 to 40 million people jobless in 2020 (UNCTAD, 2020a). COVID-19 crisis is expected to wipe out $6.7 \%$ of working hours globally in the 2nd quarter of 2020 (195 million full-time workers). In this respect other SDGs are also being deeply affected in a negative way as a result of the coronavirus pandemic, for example, Goal 2 (end hunger, achieve food security and improved nutrition), Goal 5 (achieve gender equality and empower all women and girls) and Goal 10 (reduce income inequality within and among countries). Food supply chains also suffer a big disruption, putting more fragile groups in risk. Goal 3 (good health and well-being) is also threatened, health security is a big issue due to the devastating number of deaths and infected people, as well as to many million people delaying health care for fear of contamination by the coronavirus. Inequalities are likely to rise since the most vulnerable groups (children, elderly groups, people with disabilities, women and poor people) are more exposed to the effects of the virus and access to education may be on hold for some groups during this crisis (IOM, 2000).

Alongside with the disastrous consequences the COVID-19 pandemic has some positive effects. It showed the crucial role of the collective action and the joint efforts of the governments. Beyond the actions of the international organizations, in some cases COVID-19 has also resulted in inter-govern- mental cooperation to overcome the shared challenges (Goal 17 - partnerships for the goals). There are obvious environmental benefits due to the lockdown measures (Goal 13 - climate action). One of the most important results of the pandemic is that a turn to a green recovery of the economy started (Goal 7 - clean energy).

\section{Socio-economic response of the UN and the measures for combating the coronavirus pandemic}

The crisis forced the international organizations and national governments to implement diverse measures in an attempt to curtail the pandemic and support the economy. In its Framework for the Immediate Socio-Economic Response to the COVID 19 Crisis the UN warned that "The COVID19 pandemic is far more than a health crisis: it is affecting societies and economies at their core. While the impact of the pandemic will vary from country to country, it will most likely increase poverty and inequalities at a global scale, making achievement of SDGs even more urgent. Assessing the impacts of the COVID-19 crisis on societies, economies and vulnerable groups is fundamental to inform and tailor the responses of governments and partners to recover from the crisis and ensure that no one is left behind in this effort. Without urgent socio-eco-nomic responses, global suffering will escalate, jeopardizing lives and livelihoods for years to come. Immediate development responses in this crisis must be undertaken with an eye to the future. Development trajectories in the long-term will be affected by the choices countries make now and the support they receive" (UNDP, 2020).

The United Nations has mobilized the full capacity of the UN system through its 131 country teams serving 162 countries and territories, to support national authorities in developing public health preparedness and response plans to the COVID-19 crisis. As the technical lead for the socio-economic response, UNDP and its country offices worldwide are working under the leadership of the UN Resident Coordinators, and in close collaboration with specialized UN agencies, UN Regional Economic Commissions and IFIs, to assess the socio-economic impacts of the COVID-19 pandemic on economies and communities. They have prepared assessment reports which contain the preliminary findings of regional and country analyses as well as recommendations for their recovery policy (UNDP, 2020).

While official development assistance was being directed towards humanitarian and health measures to respond to COVID-19, UNDP redirected its own 
funding to kick-start vital recovery efforts in fragile contexts. Early on, nearly half of UNDP's Rapid Response Facility of US $\$ 30$ million was allocated to fragile contexts, which catalyzed an additional US\$ 304 million or half, of UNDP's COVID-19 response in fragile contexts. Alongside this, UNDP continues to invest over half of its budget of US\$6 billion in 2020 to fragile contexts, making good on our global commitment to leave no one behind, especially during this pandemic.

In order to recover from this crisis stronger and launch a new path, the UN estimates that "a multilateral response of about $10 \%$ of global GDP will be needed". UN called a 2,5 trillion USD support package for developing countries to deal with the coronavirus shock. The financial assistance is allocated as follows:

- $\quad \$ 1$ trillion should be made available through the expanded use of special drawing rights,

- $\$ 1$ trillion of debts owed by developing countries should be cancelled this year,

- $\$ 500$ billion needed to fund a Marshall Plan for health recovery and dispersed as grants.

"The economic fallout from the shock is ongoing and increasingly difficult to predict but there are clear indications that things will get much worse for developing economies before they get better," UNCTAD Secretary-General Mukhisa Kituyi said (UNCTAD, 2020b). Obviously, the global economic recession and financial turmoil from COVID-19 are derailing implementation of the Addis Ababa Action Agenda and threatening the achievement of the Sustainable Development Goals (SDGs). Even before the pandemic, the 2020 Financing for Sustainable Development Report (FSDR) of the Interagency Task Force noted that there was backsliding in many areas. Due to the COVID-19 crisis, global financial markets have witnessed heavy losses and intense volatility. Particularly worrisome is the prospect of a new debt crisis. The FSDR highlights both immediate and longer-term actions, including arresting the backslide, to respond to the COVID-19 crisis. The FSDR calls for a globally coordinated stimulus package, including reversing the decline in aid and increased concessional finance. It recommends the following measures to prevent a debt crisis: immediately suspending debt payments from poor countries, beyond the crisis, reassess debt sustainability/revisit existing mechanisms. In order to stabilize financial markets by continuing to inject liquidity in the medium-term, explore regulatory frameworks to limit over-borrowing for non-productive investments, such as repaying shareholders. Partnering with the private sector becomes very important, so that in the short term, banks to roll over debt to SMEs and individuals that are cash strapped and in the medium-term, promote sustainable investment. Building back better for sustainable development is another priority with the following measures:

- Public and private investment in sustainable development including in resilient infrastructure.

- Strengthening social protection systems.

- Investment in crisis prevention, risk reduction and planning

- Eliminate trade barriers and restrictions that affect supply chains.

Digital technologies present tremendous potential for the SDGs, but COVID-19 has underlined challenges and risks, public policies should be adjusted to fully exploit their potential, while addressing exclusion and risks of discrimination, and ensuring benefits for society at large, including decent jobs.

\section{The EU Green Deal as a chance for reset of the economy that has been ruined by COVID-19}

To help repair the economic and social damage caused by the coronavirus pandemic, the European Commission, the European Parliament and EU leaders have agreed on a recovery plan that will lead the way out of the crisis and lay the foundations for a modern and more sustainable Europe. The EU's long-term budget, coupled with NextGenerationEU, the temporary instrument designed to boost the recovery, will be the largest stimulus package ever financed through the EU budget. EU announced a package of 540 billion and later approved 672.5 billion Euro ( 815 billion USD) for recovery and a full package of 1,8 trillion Euro (DW, 2021). Just for comparison, USA declared 2.3 trillion USD relief and funding bill, signed by President Donald Trump and another 1.9 trillion relief bill, signed by President Joe Biden. Japan has a budget of 234.2 trillion yen for recovery and announced a third package of 117 trillion Yen (1.1 trillion USD) to stimulate the economy.

The amount of 1.8 trillion of the EU is envisaged to help rebuild a post-COVID-19 Europe. It is supposed to be a greener, more digital and more resilient Europe. The EU's long-term budget, coupled with NextGenerationEU, the temporary instrument designed to boost the recovery, will be the largest stimulus package ever financed through the EU budget.

The new long-term budget is expected to increase flexibility mechanisms to guarantee it has the capacity to address unforeseen needs. It is a budget fit not only for today's realities but also for 
tomorrow's uncertainties. More than $50 \%$ of the amount supports modernization, for example through research and innovation, fair climate and digital transitions, preparedness, recovery and resilience and a new health program.

The second step in combating the coronavirus consequences is the European Green Deal which turns out to be a gateway to green economy. It presents a roadmap for making the EU's economy sustainable by turning climate and environmental challenges into opportunities across all policy areas (Figure 3). The European Green Deal aims to boost the efficient use of resources by moving to a clean, circular economy and stop climate change, revert biodiversity loss and cut pollution. It outlines investments needed and financing tools available and explains how to ensure a just and inclusive transition. The European Green Deal covers all sectors of the economy, notably transport, energy, agriculture, buildings, and industries such as steel, cement, ICT, textiles and chemicals.

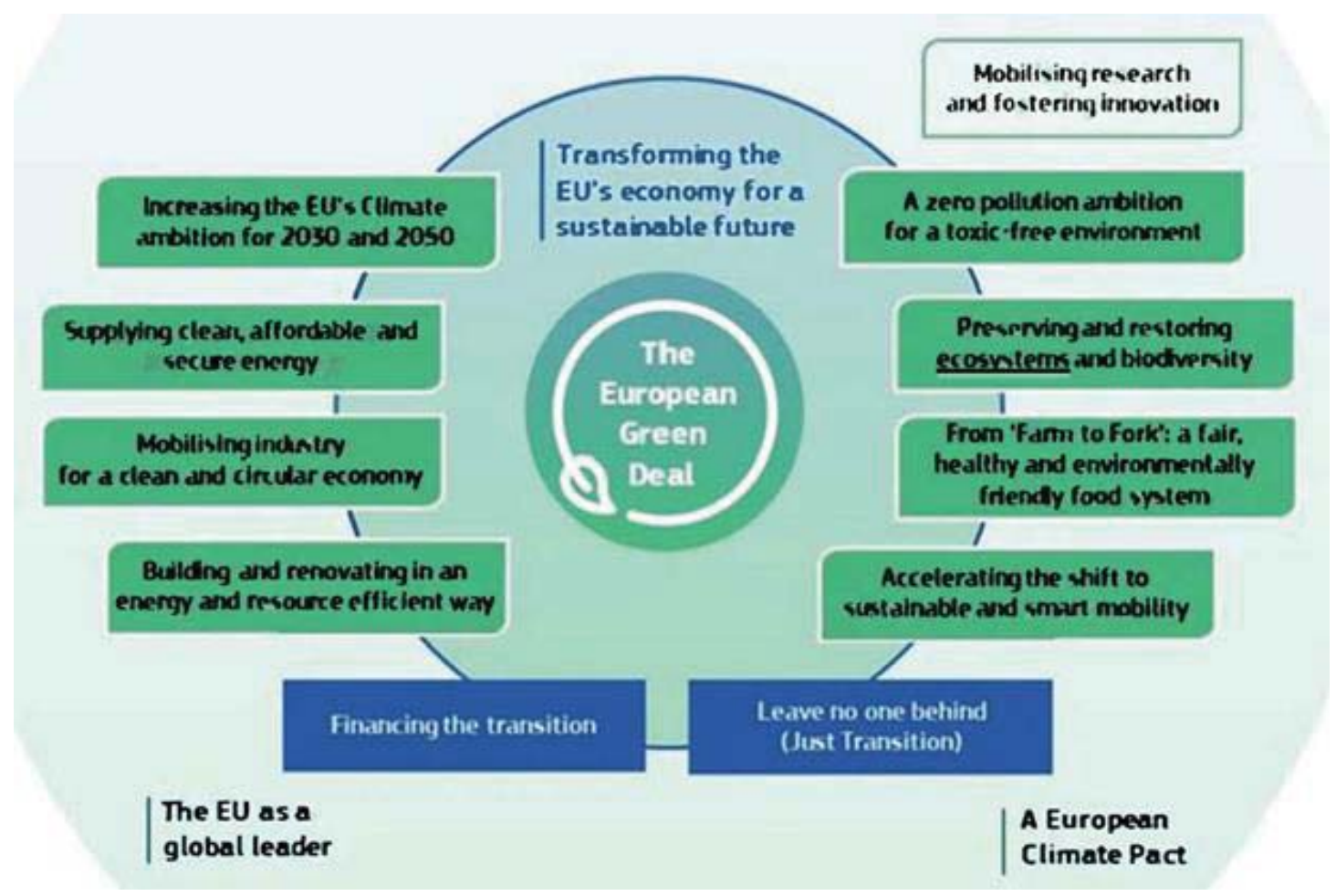

Figure 3 - Policy areas of the EU Green Deal Source: (EU, 2020)

The European Green Deal launched a strategy for a climate-neutral, resource-efficient and competitive economy. It strengthens the European Commission's commitment to tackling climate and environmental challenges. The European Green Deal is integral to the Commission's strategy to implement the United Nations 2030 Agenda and its Sustainable Development Goals (SDGs). The circular economy is considered a key approach in the process of transition to a sustainable economy model and a way to achieve certain SDGs (Bogetić et al., 2021). Scaling up the circular economy from front-runners to the mainstream economic players makes a decisive contribution to achieving climate neutrality by 2050 and decoupling economic growth from resource use, while ensuring the long-term competitiveness of the EU and leaving no one behind (EC, 2020). To fulfil this ambition, the EU has decided to accelerate the transition towards a regenerative growth model that gives back to the planet more than it takes, advance towards keeping its resource consumption within planetary boundaries, and therefore strive to reduce its consumption footprint and double its circular material use rate in the coming decade.

This progressive, yet irreversible transition to a sustainable economic system is an indispensable part of the new EU industrial strategy. A recent study estimates that applying circular economy principles across the EU economy has the potential to increase EU GDP by an additional $0.5 \%$ by 2030 creating around 700000 new jobs. There is a clear business case for individual companies too: since manufacturing firms in the EU spend on average 
about $40 \%$ on materials, closed loop models can increase their profitability, while sheltering them from resource price fluctuations.

Building on the single market and the potential of digital technologies, the circular economy has the ambition to strengthen the EU's industrial base and foster business creation and entrepreneurship among SMEs. Innovative models based on a closer relationship with customers, mass customization, the sharing and collaborative economy, and powered by digital technologies, such as internet, big data, blockchain and artificial intelligence, are expected not only to accelerate circularity but also the dematerialization of our economy and make Europe less dependent on primary materials.

The European Green Deal provides an action plan, to boost the efficient use of resources by moving to a clean, circular economy and to restore biodiversity and cut pollution. It embraces various policy areas. The Circular Economy Action Plan (CEAP) 2020 is a cornerstone of the EU Green Deal. Key to the CEAP 2020 is its established agenda to promote sustainable growth, in alignment with the new EU Green Deal. The CEAP 2020 focuses on sustainable product design, waste, urban, rural and suburban areas, as well as unlocking support for businesses through cross-cutting actions that serve to enhance the goals of the EU Green Deal. Together, the EU Green Deal and CEAP 2020 will enable an agenda to achieve a cleaner and more competitive Europe in collaboration with businesses, consumers, citizens and civil society. The four core themes of the Circular Economy Action Plan 2020 are: make sustainable products the norm in the EU, empower consumers, focus on the lifetime of products through a sectoral lens and ensure less waste.

\section{CONCLUSION}

The United Nations already declared that the Global Agenda for the Sustainable Development Goals for 2030 is under stress and the whole world needs to act together to accelerate a quick recovery. The SDGs emerge, as never before, as a guiding light for the companies' safer path towards an uncertain future, where one thing is certain: the wellbeing of the society is crucial for business success. SDGs are, as mentioned by UN General Secretary, able "to lead to a different economy more equal, inclusive and sustainable, to be more resilient to pandemics, climate change, and other global challenges", where business can succeed hand in hand with society.

This research analyzed the impact of COVID-19 on the sustainable development agenda and the challenges ahead for the states and the business. It also highlights the immense opportunity COVID-19 represents as a reset moment for the world and as a chance for the corporate sector to take leadership and definitely embrace sustainability as a strategy for its own success and a global shared prosperity.

COVID-19 is an unprecedented disaster, but it is also a tremendous opportunity for an economic reset. A stand up from the ashes, from a short-term vision that destroys the environment to a new economic model where "no one is left behind". As the United Nations confirm, COVID-19 can mark "the rebirth of society as we know it today to one where we protect present and future generations".

\section{REFERENCES}

[1] Bogetić, S., Đorđević, D., Ćočkalo, D., Đorđević, L. and Bakator, M. (2021). The circular economy and global market challenge, Ecologica, 28(101), 65-71.

[2] Bureau of Economic Analysis (2021). Gross Domestic Product, First Quarter 2021 (Advance Estimate), April 29, 2021. Available at: https://www.bea.gov/news/2021/grossdomestic-product-first-quarter-2021-advanceestimate

[3] Center for Responsible Business \& Leadership (2020), The Impact of COVID-19 on the Sustainable development, CATOLICA-LISBON, Available at:

https://www.clsbe.lisboa.ucp.pt/research-notethe-impact-of-covid-19-on-the-sustainabledevelopment-agenda-a-business-opportunityto-reframe-the-future-

[4] DW (2021). Deutsche Welle News, 10.02.2021, available at https://www.dw.com/en/europeanparliament-passes-6725-billion-covidrecovery-fund/a-56528327

[5] EC (2020). Circular Economy Action Plan: The European Green Deal, EU, Available at https://ec.europa.eu/environment/circulareconomy/pdf/new_circular_economy_action_p lan.pdf

[6] EU (2020), The EU Green Deal - a roadmap to sustainable economies, Available at: https://www.switchtogreen.eu/the-eu-greendeal-promoting-a-green-notable-circulareconomy/

[7] International Monetary Fund (2021). COVID-19 Recovery Contributions, available at https://www.imf.org/en/Publications/SPROLLs/ covid19-special-notes 
[8] International Monetary Fund (2020). World Economic Outlook. October 2020: A Long and Difficult Ascent. Washington DC.

[9] International Organization for Migration (2020), How the COVID-19 affect the achievement of the goals of the 2030 Agenda, Available at: https://rosanjose.iom.int/site/en/blog/how-willcovid-19-affect-achievement-goals-2030agenda

[10] Ivanović, O.M. and Vujić, M. (2021), Posledice delovanja COVID-19 na ekonomski sektor i životnu sredinu, Ecologica, 28(101), 118-124.

[11] Marx, A. (2019). PPPs for Sustainable Development: Exploring Their Design and Its Impact on Effectiveness, Sustainability, 11, 1-9

[12] Pedamon, C. and Vassileva, R. (2021). Contractual Performance in COVID-19 Times: Does Anglo-French History Repeat Itself?, European Review of Private Law, No.1, 3-38.

[13] Sumner, A., Hoy, C. and Ortiz-Juarez, E. (2020). Estimates of the impact of COVID-19 on global poverty. WIDER Working Paper 2020/43. United Nations University, World Institute for Development Economics Research.

[14] United Nations (2020). Available at: https://www.undp.org/content/undp/en/home/p resscenter/pressreleases/2020/COVID19_Cris is in developing countries threatens devast ate_economies.html
[15] UNCTAD (2020a). Impact of the COVID-19 Pandemic on Trade and Development. Transition to a New Normal, Geneva, Available at: https://unctad.org/system/files/officialdocument/osg2020d1_en.pdf

[16] UNCTAD (2020b). UN calls for $\$ 2.5$ trillion support package for developing countries to deal with coronavirus shock, Available at: https://unctad.org/press-material/un-calls-25trillion-support-package-developing-countriesdeal-coronavirus-shock

[17] UNDP (2017). The Millennium Development Goals Report 2015, UNDP, available at: https://www.undp.org/content/undp/en/home/li brarypage/mdg/the-millennium-developmentgoals-report-2015.html

[18] UNDP (2020). Brief\#2: Putting the UN Framework for Socio-economic Response to COVID-19 into Action: Insights, Available at: https://www.undp.org/content/undp/en/home/c ovid-19-pandemic-response/socio-economicimpact-of-covid-19.html

[19] Vassileva, A., Simić, M. and Stevanović, M. (2020). Implications of COVID-19 for International Business, Ecologica, 27(100), 589-596.

[20] WBCSD (2020), Circular Economy Action Plan (CEAP) 2020 summary for business, Geneva, Available at: https://docs.wbcsd.org/2020/11/WBCSD_Circ ular_Economy_Action_Plan_2020\%E2\%80\%9 3Summary_for_business.pdf. 